\title{
Water deficit and plant recovery affect interaction between soybean and slender amaranth
}

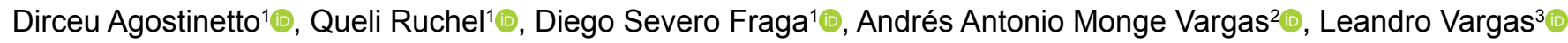 \\ 1 Universidade Federal de Pelotas, Pelotas, RS, Brasil. .E-mail: agostinetto.d@gmail.com; queli.ruchel@yahoo.com.br; fragadiegos@gmail.com \\ 2 Universidad de Costa Rica, San Jose, San Pedro, Costa Rica. E-mail: amova11@gmail.com \\ ${ }^{3}$ Embrapa Trigo, Passo Fundo, RS, Brasil. E-mail: leandro.vargas@embrapa.br
}

ABSTRACT: Biotic and abiotic factors such as competition with weeds and water deficit may cause significant losses to soybean productivity. This study aimed at evaluating the effect of water deficit and plant recovery in the interaction between soybean (Glycine max) and slender amaranth (Amaranthus viridis) by using growth variables. A replacement series experiment was performed and treatments were arranged in a factorial scheme; they were composed of two water regimes (field capacity and water deficit (50\% of field capacity)) and different soybean and slender amaranth proportions (100:0, 50:50 and 0:100\%). Water regimes were applied 20 days after plant transplant. Height, leaf area and shoot dry matter were evaluated in soybean and slender amaranth under field capacity and water deficit, returning to normal irrigation conditions to evaluate the water recovery. Soybean exhibited competitiveness which was equivalent to the slender amaranth, independent of the water regime. Water deficit negatively influenced height, leaf area and shoot dry matter of soybean and slender amaranth. There was a reduction in leaf area and shoot dry matter of soybean after plant recovery caused by the irrigation deficit period.

Key words: Amaranthus viridis; competition; Glycine max; replacement series; water stress

\section{Déficit hídrico e recuperação das plantas afeta a interação entre soja e caruru}

RESUMO: Fatores bióticos e abióticos, como a competição com plantas daninhas e déficit hídrico podem causar perdas significativas na produtividade da soja. 0 objetivo do estudo foi avaliar o efeito do déficit hídrico e recuperação das plantas na interação entre soja (Glycine max) e caruru (Amaranthus viridis) através de variáveis de crescimento. Conduziu-se 0 experimento em série de substituição e os tratamentos foram arranjados em esquema fatorial, sendo constituídos por dois regimes hídricos (capacidade de campo e déficit hídrico (50\% da capacidade de campo)) e, por proporções de plantas de soja e caruru (100:0, 50:50 e 0:100\%). Os regimes hídricos foram aplicados aos 20 dias após o transplante das plantas. Avaliou-se estatura, área foliar e matéria seca da parte aérea em soja e caruru sob capacidade de campo e déficit hídrico, retornando as condições normais de irrigação para avaliar a recuperação hídrica. A soja demonstrou competitividade equivalente ao caruru independente do regime hídrico. 0 déficit hídrico influenciou negativamente a estatura, áera foliar e massa seca da soja e caruru. Após recuperação das plantas, observou-se redução da área foliar e massa seca da soja, causado pelo período de irrigação deficitária.

Palavras-chave: Amaranthus viridis; competição; Glycine max; série substitutiva; estresse hídrico 


\section{Introduction}

Soybean has high social and economic relevance as it is the main annual crop in Brazilian agriculture. However, several biotic and abiotic factors such as competition with weeds and long periods of water deficit may cause significant losses in its productivity. Stress conditions which result from competition and/or water deficit lead to short-term and long-term effects by inducing a set of responses which helps plants adapt to limiting environmental circumstances depending on stress intensity and duration, interactive effects of other stresses, developmental stage and genotype (Meneses et al., 2006; Wijewardana et al., 2019).

Damage caused by weeds mainly results from competition for environmental resources and may decrease soybean productivity by up to $93 \%$ (Silva et al., 2009). However, losses depend on cultivars and management practices, in addition to weed species, population, emergence period and phenological stage since they provide different competition levels (Agostinetto et al., 2014). Species which are morphophysiologically close usually have similar demands for resources, and constitutes a fact which makes competition more intense.

Since soybean has a relatively high demand for water, any annual rainfall distribution below expectation leads to damage to production (Morando et al., 2014). Water availability is especially important in two periods of soybean development, being between seed germination and seedling emergence and from flowering to pod filling, because it participates in all physiological and biochemical processes (Farias et al., 2009). Long drought periods may affect plant height, internode length, growth rate, leaf area index, number of legumes, seeds per legume and grain weight, thus leading to a decrease in productivity (Desclaux et al., 2000).

It is fundamental to know about the interference of water deficit and the competition between crops and weeds so as to avoid choosing management practices in conditions which are not ideal for cultivation since they are considered the main factors which limit plant growth and productivity, and induce changes at different hierarchical levels. Therefore, this study aimed at evaluating the effect of water deficit and plant recovery in the interaction between crops and weeds by using growth variables.

\section{Materials and Methods}

The experiment was conducted in a greenhouse from November 2015 to January 2016 implementing a completely randomized design with eight replicates. The NA 5909 RG soybean cultivar and slender amaranth seeds were collected in a non-agricultural area. Experimental units were 4-liter pots with diameters of $22 \mathrm{~cm}$. Sowing was carried out on polystyrene trays. Plants of both species were transplanted to pots when their first set of true leaves had expanded. The soil was classified into Red-yellow Argissol with sandy loam texture. Fertility was corrected based on the soil analysis by applying $220 \mathrm{~kg} \mathrm{ha}^{-1}$ of NPK fertilizer (05-20-20).
Treatments were arranged in a factorial scheme, with factor A being composed of different water regimes (field capacity and water deficit ( $50 \%$ of field capacity)) and factor B comprised the following proportions of soybean and slender amaranth: 100:0 (pure soybean stand), 50:50 and 0:100\% (pure slender amaranth stand), equivalent to $10: 0,5: 5$ and $0: 10$ plants pot ${ }^{-1}$.

The plant population was determined by a previous experiment in which populations of 8-12 plants were found per experimental unit, equivalent to populations of 193 and 289 plants $\mathrm{m}^{-2}$ in the cases of soybean and slender amaranth, respectively, in agreement with the "law of constant final yield" (Radosevich et al., 2007) (data not shown). Population per experimental unit was found by calculating arithmetic means of populations; it resulted in 10 plants pot ${ }^{-1}$, equivalent to 241 plants $\mathrm{m}^{-2}$.

Plants were kept in a greenhouse up to 20 days after transplant (DAT) at equal humidity and temperature conditions, and treatments with different water regimes were subsequently applied (field capacity and water deficit (50\% of field capacity)). Fifty percent of water available in every pot daily was applied based on the estimate of total water availability which had been previously determined by the difference between a completely saturated pot and dry weight (before water was added), as described by Valerio et al. (2011). Pots were weighed daily and the volume of $50 \%$ water was applied up to the first sign of leaf wilting, after approximately 6 days. Afterwards, water was re-applied to the point of field capacity for 2 days and then the drought cycle was carried out weekly for two weeks.

The analysis of variables under field capacity and water deficit was carried out 45 DAT ( 25 days after the water regime) in four replicates of every treatment. Height, leaf area and shoot dry matter of soybean and its competitor (soybean in $\mathrm{V}_{6}$ $\mathrm{V}_{8}$ stages; slender amaranth with 9-10 leaves) were evaluated. Four experimental units submitted to water deficit were reverted to control conditions (field capacity) at 45 DAT so that plant recovery could be evaluated. Height, leaf area and shoot dry matter were evaluated in field capacity and water deficit recovery treatments at 55 DAT 10 days after recovery (soybean in R1 stage; slender amaranth with 10-12 leaves).

Height was measured in all plants in every replicate by a millimeter ruler from the soil level to the leaf apex with blade distended. Leaf area was determined by a LI $3200 \mathrm{C}$ leaf area meter; values were expressed as $\mathrm{cm}^{2}$ and converted into $\mathrm{cm}^{2}$ plant $^{-1}$. Shoot dry matter was quantified after drying was carried out in a forced air circulation oven at $60{ }^{\circ} \mathrm{C}$ for $72 \mathrm{~h}$. Values were expressed as g plant ${ }^{-1}$.

The graphical analysis method of relative productivity (Radosevich, 1987; Cousens, 1991), as described by Ruchel et al. (2019) and Silva et al. (2017), was used for analyzing data on height, leaf area and shoot dry matter. The criterion to consider the existence of diferences in competitive abilities for relative competitiveness indexes, coefficients of relative grouping and competitiveness was that there should be differences in at least two of them by the T-test (Bianchi et al., 2006). Data on height, leaf area and shoot dry matter (expressed as mean 
values per plant) were submitted to the analysis of variance ( $p$ $\leq 0.05)$. When statistical significance was found by the F-test ( $p \leq 0.05)$, proportions were compared by the T-test ( $p \leq 0.05$ ) for every competitive species and analyzed separately for every water regime.

\section{Results and Discussion}

Regarding the height of soybean and slender amaranth plants growing together in both water regimes (field capacity and water deficit), deviation from the relative productivity straight line was found to be represented by a convex line 45 DAT, thus differing significantly from the hypothetical straight line (Figures $1 A-B$ and Table 1 ). The species were found to exhibit similar competitiveness in this situation, regardless of the water regime which was used.

When height was evaluated 55 DAT, deviation found in the relative productivity straight line for soybean in both treatments under investigation was represented by a line that was similar to the hypothetical straight line (Figures $1 \mathrm{C}$ and
Table 1). However, the deviation found for slender amaranth in the relative productivity straight line was represented by a line which was similar to the hypothetical straight line in the field capacity treatment and by concave lines in the water deficit recovery treatment (Figures 1D). In this case, the soybean crop was not affected by the competitor, but slightly influenced it after the period of water stress. Bianchi et al. (2011) achieved different results from ours, since competition with radish (Raphanus sativus L.) in the vegetative stage of soybean led to a decrease in height, branch length and grain productivity. A study of sunflower plants grown alone and together with slender amaranth (Amaranthus spinosus) showed that the water deficit regime affected the growth rate of the crop and led to shorter plants (Soares et al., 2019).

Total relative productivity of the variable height exhibited convex curves and significant differences between observed straight lines and expected lines 45 DAT for both field capacity and water deficit treatments (Figures $1 \mathrm{~A}-\mathrm{B}$ and Table 1 ). The evaluation performed after stress recovery (55 DAT) did not show any difference in total relative productivity.
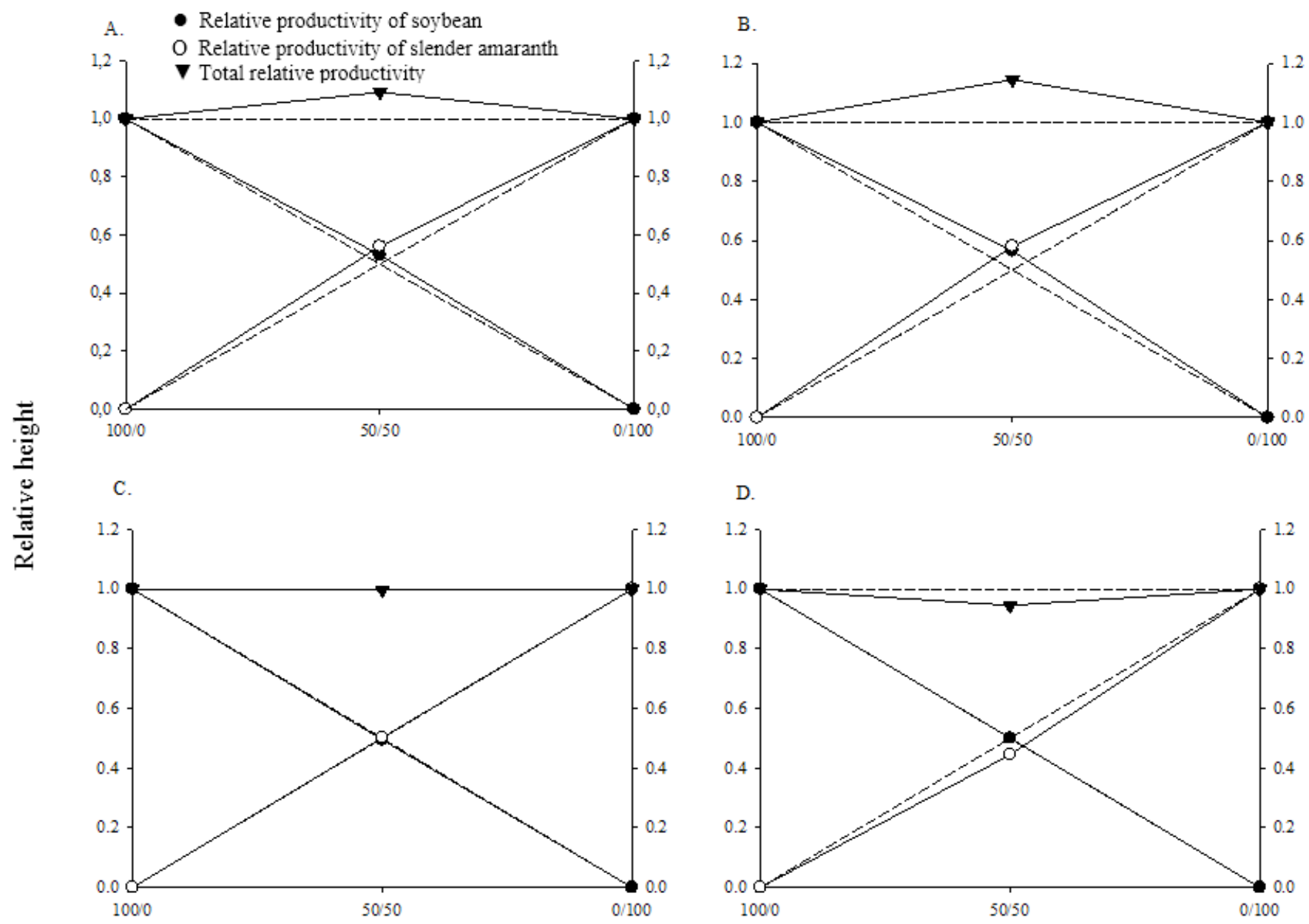

Proportions of soybean and slender amaranth (\%)

Figure 1. Relative productivity and total relative productivity for the height of soybean and slender amaranth plants as a result of the proportions between species in the population conducted 45 DAT [field capacity (A) and water deficit (B)] and 55 DAT [field capacity $(C)$ and water deficit recovery (D)]. ( $\bullet$ ) relative productivity of soybean; (O) relative productivity of slender amaranth; and ( $\nabla$ ) total relative productivity. Dashed lines refer to hypothetical relative productivity values when species do not interfere with each other. 
Table 1. Relative productivity differences (RPD) for the height, leaf area, shoot dry matter and total relative productivity (TRP) variables at a 50:50 (\%) proportion of soybean associated with slender amaranth plants conducted at 45 DAT (field capacity and water deficit) and 55 DAT (field capacity and water deficit recovery).

\begin{tabular}{|c|c|c|c|c|}
\hline \multirow{2}{*}{ Variable } & \multicolumn{2}{|c|}{45 DAT } & \multicolumn{2}{|c|}{55 DAT } \\
\hline & Field capacity & Water deficit & Field capacity & Water deficit recovery \\
\hline & \multicolumn{4}{|c|}{ Height } \\
\hline $\mathrm{RPD}_{\text {soybean }}$ & $0.03( \pm 0.01)^{*}$ & $0.06( \pm 0.02) *$ & $-0.00( \pm 0.03)^{n s}$ & $0.00( \pm 0.02)^{n s}$ \\
\hline $\mathrm{RPD}_{\text {slender amaranth }}$ & $0.06( \pm 0.02) *$ & $0.08( \pm 0.01) *$ & $0.00( \pm 0.02)^{\mathrm{ns}}$ & $-0.06( \pm 0.01)^{*}$ \\
\hline \multirow{2}{*}{ TRP } & $1.09( \pm 0.02)^{*}$ & $1.14( \pm 0.03)^{*}$ & $1.00( \pm 0.02)^{n s}$ & $0.95( \pm 0.02)^{n s}$ \\
\hline & \multicolumn{4}{|c|}{ Leaf area } \\
\hline \multirow[t]{2}{*}{ TRP } & $1.12( \pm 0.03) *$ & $1.11( \pm 0.02)^{*}$ & $0.90( \pm 0.02) *$ & $0.90( \pm 0.01) *$ \\
\hline & \multicolumn{4}{|c|}{ Shoot dry matter } \\
\hline $\mathrm{RPD}_{\text {soybean }}$ & $0.03( \pm 0.02)^{n s}$ & $0.06( \pm 0.02) *$ & $0.03( \pm 0.06)^{n s}$ & $0.03( \pm 0.02)^{n s}$ \\
\hline $\mathrm{RPD}_{\text {slender amaranth }}$ & $0.04( \pm 0.01) *$ & $-0.06( \pm 0.01) *$ & $-0.06( \pm 0.02) *$ & $-0.03( \pm 0.02)^{n s}$ \\
\hline TRP & $1.06( \pm 0.03)$ ns & $1.00( \pm 0.02) \mathrm{ns}$ & $0.97( \pm 0.06)^{n s}$ & $1.00( \pm 0.04)^{n s}$ \\
\hline
\end{tabular}

${ }^{n s}$ Non-significant; * Significant, by comparison with the hypothetical straight line, by the T-test $(p \leq 0.05)$. Values between parentheses represent standard errors of means.

Regarding the variable leaf area 45 DAT, deviation found in the relative productivity straight line was represented by convex lines, with significant differences for the soybean crop in both treatments under evaluation. Deviation in the case of slender amaranth was represented by a convex line in both treatments and no significant difference was found (Figures $2 A-B$ and Table 1). Thus, there was no damage to the leaf area of weed $C_{4}$ submitted to water deficit and an increase in $\mathrm{C}_{3}$ plants.
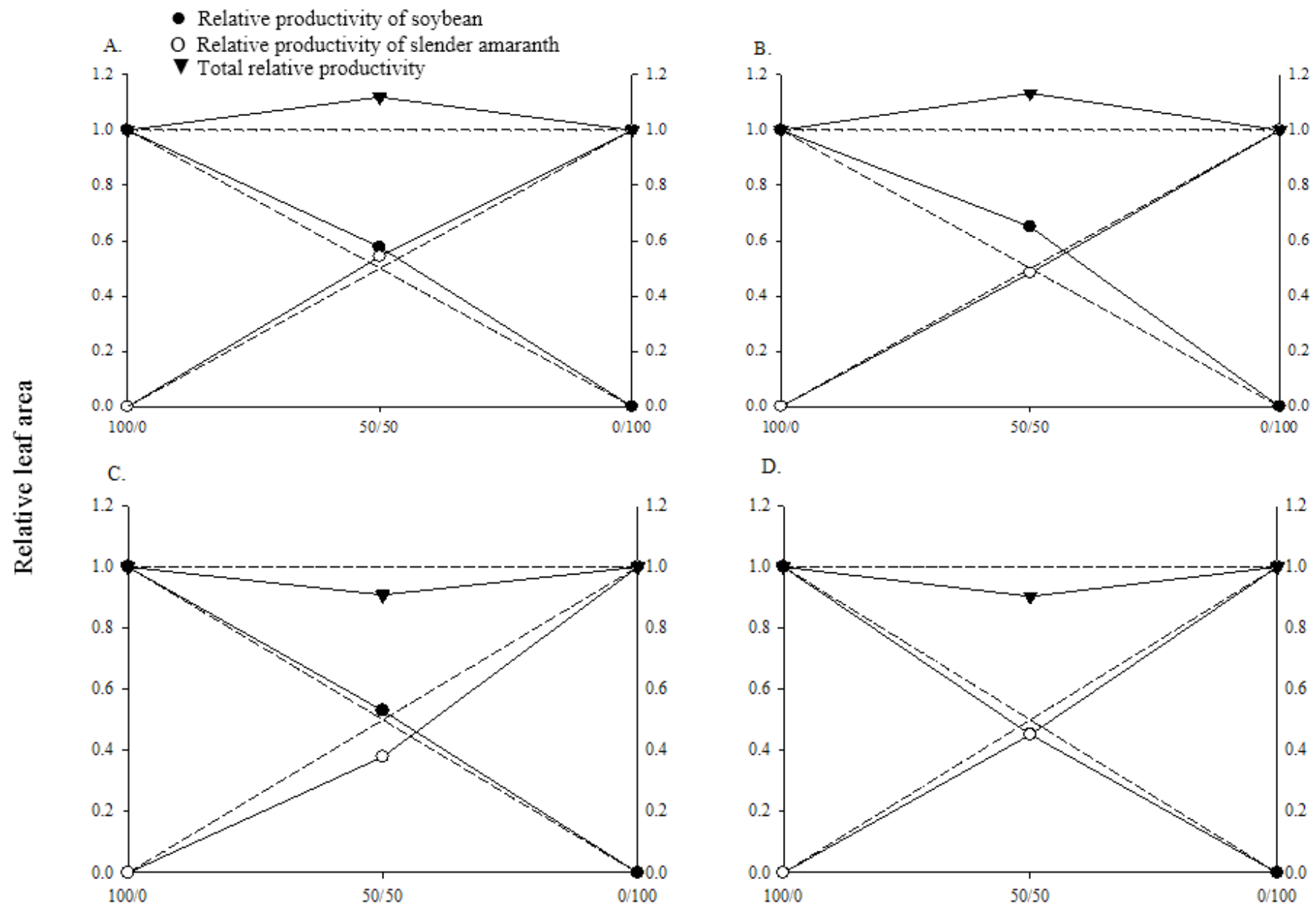

Proportions of soybean and slender amaranth (\%)

Figure 2. Relative productivity and total relative productivity for leaf area of soybean and slender amaranth plants as the result of proportions between species in the population conducted at 45 DAT [field capacity (A) and water deficit (B)] and 55 DAT [field capacity $(C)$ and water deficit recovery (D)]. (•) relative productivity of soybean; (O) relative productivity of slender amaranth; and ( $\nabla$ ) total relative productivity. Dashed lines refer to hypothetical relative productivity values when species do not interfere with each other. 
In the case of leaf area, deviation in the relative productivity straight line found at 55 DAT was represented by convex lines for soybean and by concave ones for slender amaranth in the field capacity treatment. However, there were concave lines for both species in the water deficit recovery treatment; differences were not significant for the crop, but they were significant for the weed (Figures 2C-D and Table 1). Significant convex lines were found regarding total relative productivity of leaf area at 45 DAT, while significant concave ones were found 55 DAT.

Deviation in relative productivity regarding shoot dry matter at 45 DAT was represented by convex lines for the crop and the weed in both treatments (Figures $3 A-B$ and Table 1), while convex lines for soybean and concave lines for slender amaranth were found 55 DAT in both treatments (Figures 3C-D). However, relative diferences between observed and expected straight lines at 45 DAT were only significant in the water deficit treatment for soybean. Furthermore, differences were found for slender amaranth in both treatments, while no differences were observed in total relative productivity (Table 1). In addition, variables did not lead to any relative productivity differences of soybean at 55 DAT. Relative productivity differences of slender amaranth competing with soybean were observed in the field capacity treatment, while total relative productivity did not show differences in any treatment under study.

Regardless of the water regime under investigation in the case of variable shoot dry matter, the competitive ability of soybean in cycle $C_{3}$ was generally similar to the one of the $\mathrm{C}_{4}$ weed, except in the field capacity treatment at 55 DAT, in which its competitiveness was higher than the one of slender amaranth. A study of competitive ability of barley cultivars (Hordeum vulgare L.) growing together with ryegrass exhibited concave lines for variables leaf area and shoot dry matter. This
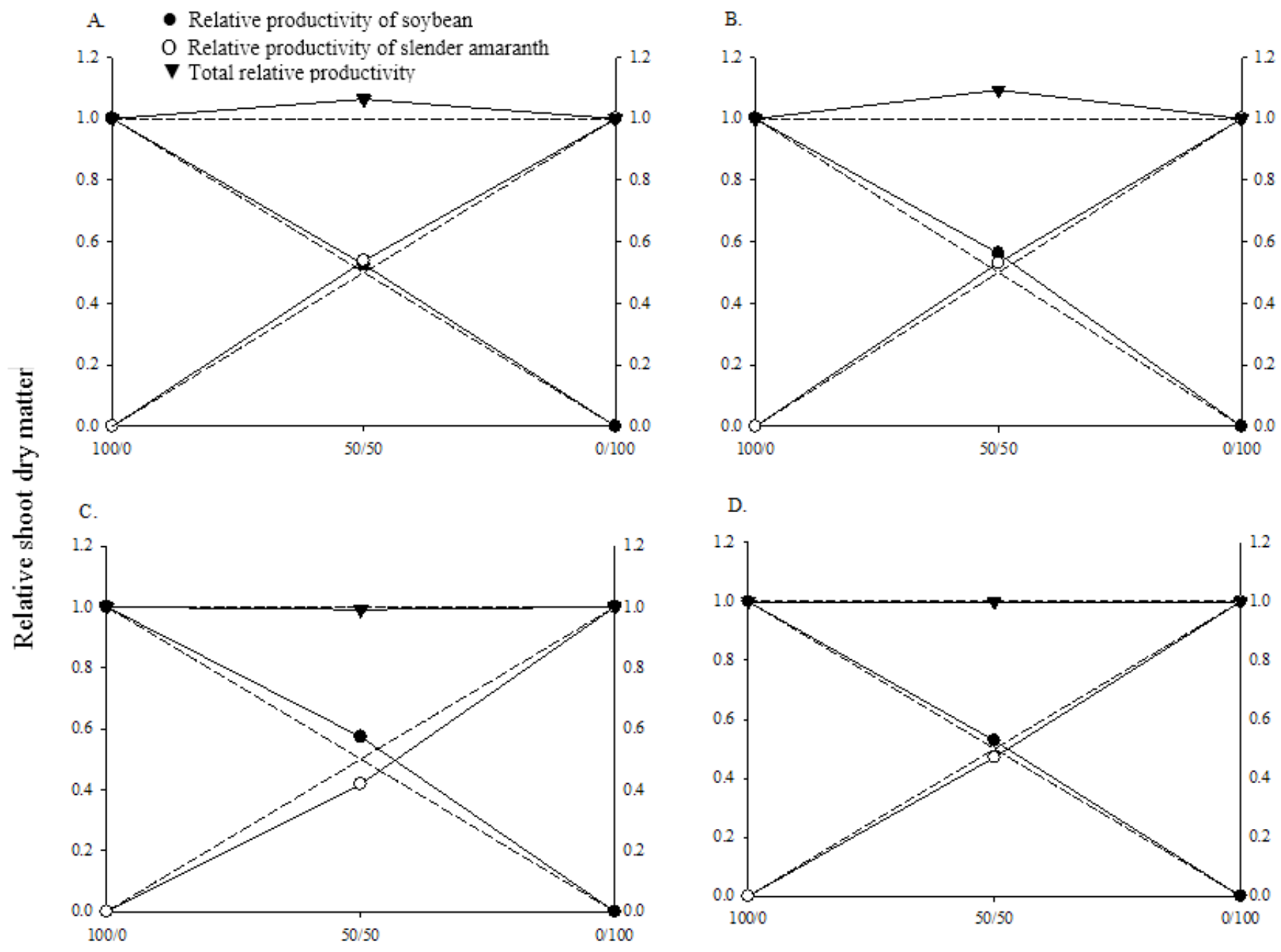

Proportions of soybean and slender amaranth (\%)

Figure 3. Relative productivity and total relative productivity for shoot dry matter of soybean and slender amaranth plants as the result of proportions between species in the population conducted at 45 DAT [field capacity (A) and water deficit (B)] and 55 DAT [field capacity $(C)$ and water deficit recovery $(D)$ ]. $(\bullet)$ relative productivity of soybean; $(O)$ relative productivity of slender amaranth; and $(\boldsymbol{\nabla})$ total relative productivity. Dashed lines refer to hypothetical relative productivity values when species do not interfere with each other. 
shows that there was competition for environmental resources and mutual damage to their growth (Galon et al., 2011). The authors also reported that the weed decreased crop tillering, leaf area and shoot dry matter in a highly competitive process for available resources.

The crop had its shoot dry matter more intensely decreased when competing with soybean, morning glory and wild poinsettia by the former than by the latter, when these species were established before the crop (Rizzardi et al., 2004). In mixed communities, the authors noted that morning glory is more competitive than wild poinsettia. The shoot dry matter of roots reduced by 64 and 49\%, respectively, when the density of rye (Secale cereale L.) and wheat growing together was increased (Far et al., 2017). Moreover, the authors observed that shoot dry matter of rye decreased by 37,47 and $33 \%$ in water deficit conditions with interspecific and intraspecific competition, respectively. Freitas et al. (2019) reported that there was competition for resources among maize, black-jack (Bidens pilosa) and signal grass (Urochloa decumbens), even when the amount of water in the soil was close to the field capacity. A decrease in growth due to either intra or interspecific competition results from spatial competition among plants.

Soybean is considered more competitive than slender amaranth when relative competitiveness $>1$, coefficients of relative grouping of soybean $>$ slender amaranth and competitiveness $>0$ (Hoffman \& Buhler, 2002), and differences should occur in at least two of the indices in order to prove its competitive superiority (Bianchi et al., 2006). Thus, the soybean in cycle $C_{3}$ at 45 DAT was generally found to exhibit competitiveness equivalent to that of the weed $\left(C_{4}\right)$ when field capacity and water deficit treatments were compared. In this case, field capacity conditions only showed significance for leaf area, while water deficit conditions exhibited significance for shoot dry matter, partly corroborating the graphical analysis results (Table 2). Since there was only significance for shoot dry matter in the water deficit recovery treatment at 55 DAT, soybean and slender amaranth were found to have similar competitiveness.

Lamego et al. (2013) found similar results to those reported herein when they evaluated competitive abilities of wheat cultivars, ryegrass and turnips. Other studies which used these three indexes to define competitiveness showed that great millet was more competitive than Johnson grass (Sorghum halepense L.) (Hoffman \& Buhler, 2002), ryegrass was more competitive than barley (Galon et al., 2011) and beans had more competitive ability than beggarticks (Galon et al., 2017).

Concerning the soybean crop, a simple effect of both factors (water regime and plant ratio) was found in the height and leaf area variables at 45 DAT, while a simple effect of the water regime was found for shoot dry matter. A simple effect of both factors was found for weed height and a simple effect of the water regime was found for leaf area and shoot dry matter of slender amaranth. A simple effect of the water regime was further observed for soybean leaf area and shoot dry matter at 55 DAT, but no statistical significance was found for height. A simple effect of plant ratio on weed leaf area and shoot dry matter was also observed, while no statistical significance was found for height.

The highest soybean height and leaf area was found 45 DAT when the crop was well irrigated (Figures $4 A$ and $B$ ) and when it grew together with slender amaranth (Figures $5 \mathrm{~A}$ and $B)$. This demonstrates that intraspecific competition tended to be more harmful to the crop in both water regimes under investigation, mainly in water deficit. However, soybean shoot dry matter was only higher in the field capacity condition than in the water deficit one, regardless of plant ratio (Figure 4C). There was increase in height regarding slender amaranth at 45 DAT when it grew together with soybean (Figure 5A), while

Table 2. Competitiveness indexes between soybean and slender amaranth evaluated at 45 DAT (field capacity and water deficit) and 55 DAT (field capacity and water deficit recovery), expressed as relative competitiveness (RC), coefficients of relative grouping (K) and competitiveness (C).

\begin{tabular}{|c|c|c|c|c|}
\hline \multirow{2}{*}{ Indexes } & \multicolumn{2}{|c|}{45 DAT } & \multicolumn{2}{|c|}{55 DAT } \\
\hline & Field capacity & Water deficit & Field capacity & Water deficit recovery \\
\hline & \multicolumn{4}{|c|}{ Height } \\
\hline $\mathrm{RC}$ & $0.95( \pm 0.02)^{n s}$ & $0.97( \pm 0.02)^{n s}$ & $0.99( \pm 0.09)^{n s}$ & $1.13( \pm 0.08)^{n s}$ \\
\hline $\mathrm{K}_{\text {soybean }}$ & $1.14( \pm 0.04)^{n s}$ & $1.31( \pm 0.09)^{n s}$ & $1.00( \pm 0.11)^{n s}$ & $1.02( \pm 0.10)^{n s}$ \\
\hline Kslender amaranth & $1.29( \pm 0.08)$ & $1.39( \pm 0.06)$ & $1.02( \pm 0.07)$ & $0.81( \pm 0.04)$ \\
\hline $\mathrm{C}$ & $-0.03( \pm 0.01)^{n s}$ & $-0.02( \pm 0.01)^{n s}$ & $-0.01( \pm 0.04)^{n s}$ & $0.06( \pm 0.03) \mathrm{ns}$ \\
\hline$K_{\text {soybean }}$ & $1.37( \pm 0.09) *$ & $1.76( \pm 0.21)^{\mathrm{ns}}$ & $0.84( \pm 0.09)^{n s}$ & $0.84( \pm 0.05)^{n s}$ \\
\hline Kslender amaranth & $1.19( \pm 0.08)$ & $0.94( \pm 0.06)$ & $0.81( \pm 0.04)$ & $0.83( \pm 0.05)$ \\
\hline \multirow[t]{2}{*}{$\mathrm{C}$} & $0.03( \pm 0.01) *$ & $0.15( \pm 0.04) *$ & $0.01( \pm 0.04)^{n s}$ & $0.00( \pm 0.03)^{n s}$ \\
\hline & \multicolumn{4}{|c|}{ Shoot dry matter } \\
\hline $\mathrm{RC}$ & $0.98( \pm 0.03)^{n s}$ & $1.27( \pm 0.02)^{*}$ & $1.22( \pm 0.14)^{n s}$ & $1.12( \pm 0.03)^{*}$ \\
\hline
\end{tabular}

${ }^{n s}$ Non-significant; ${ }^{*}$ Significant by the T-test $(p \leq 0.05)$. Values between parentheses represent standard errors of means. 
A.

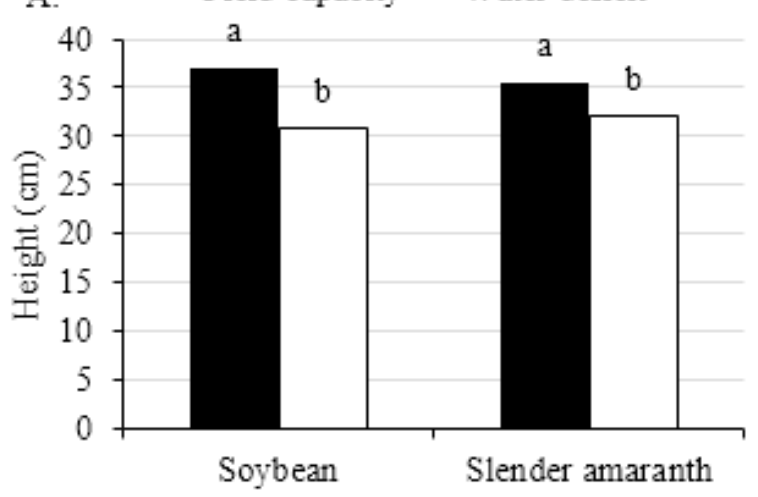

B.
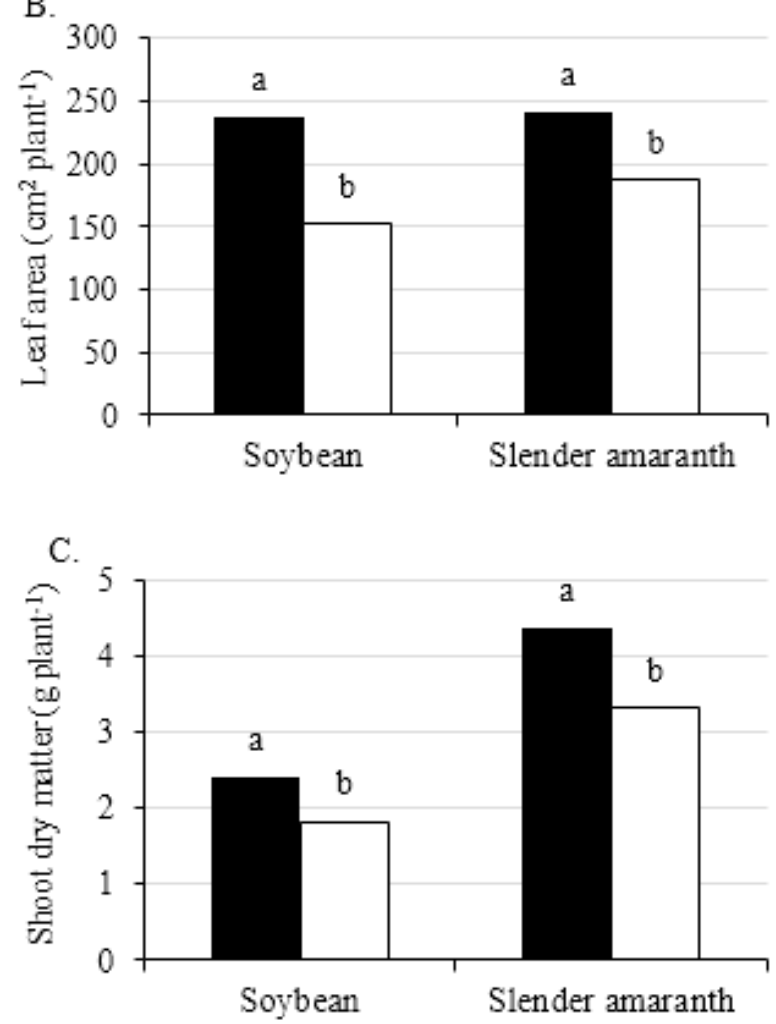
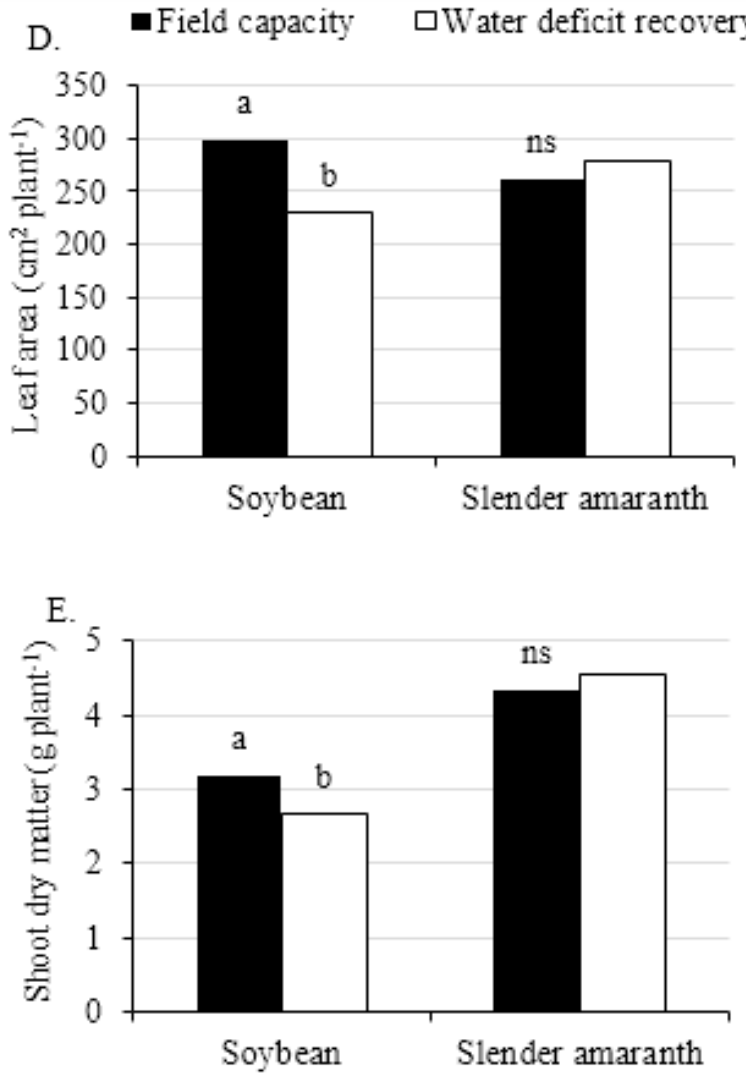

Figure 4. Height, leaf area and shoot dry matter of soybean and slender amaranth as a response to different water regimes

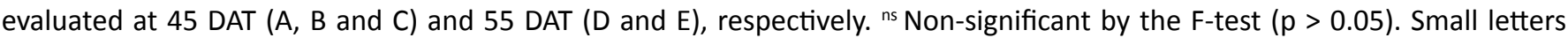
compare different water regimes for every species by the T-test $(p \leq 0.05)$.

water deficit decreased plant height, leaf area and shoot dry matter by comparison with field capacity (Figures $4 A-C$ ). Thus, it may be inferred that competition did not interfere in the variables under study for slender amaranth, and they decreased when irrigation was deficient.

The analysis of coatbutton (Tridax procumbens L.) growth, a $\mathrm{C}_{3}$ species competing with soybean, showed that the crop not only had higher height, leaf area and shoot dry matter than the weed even when undergoing temporary water deficit, but also exhibited high intraspecific competition (Vivian et al., 2013).

The soybean crop showed a decrease in leaf area and shoot dry matter in the water deficit recovery treatment at 55 DAT (Figures $4 \mathrm{D}$ and $\mathrm{E}$ ), regardless of the plant ratio (Figures $5 \mathrm{C}$ and
D). Even after adequate irrigation conditions were reverted, soybean exhibited a decrease in morphological variables due to the stress caused by the deficient irrigation period. There was generally a decrease in leaf area and shoot dry matter for slender amaranth when it grew together with soybean (Figures $5 \mathrm{C}$ and $\mathrm{D}$ ), showing that interspecific competition was harmful to the weed in this stage since it caused a decrease in morphological variables, regardless of the water regime under study.

A study which was carried out to evaluate the interference of redroot pigweed (Amaranthus retroflexus L.) in cotton showed that heights and diameters of cotton stems decreased as weed density increased (Ma et al., 2015). The authors also observed that the effect of intraspecific competition 

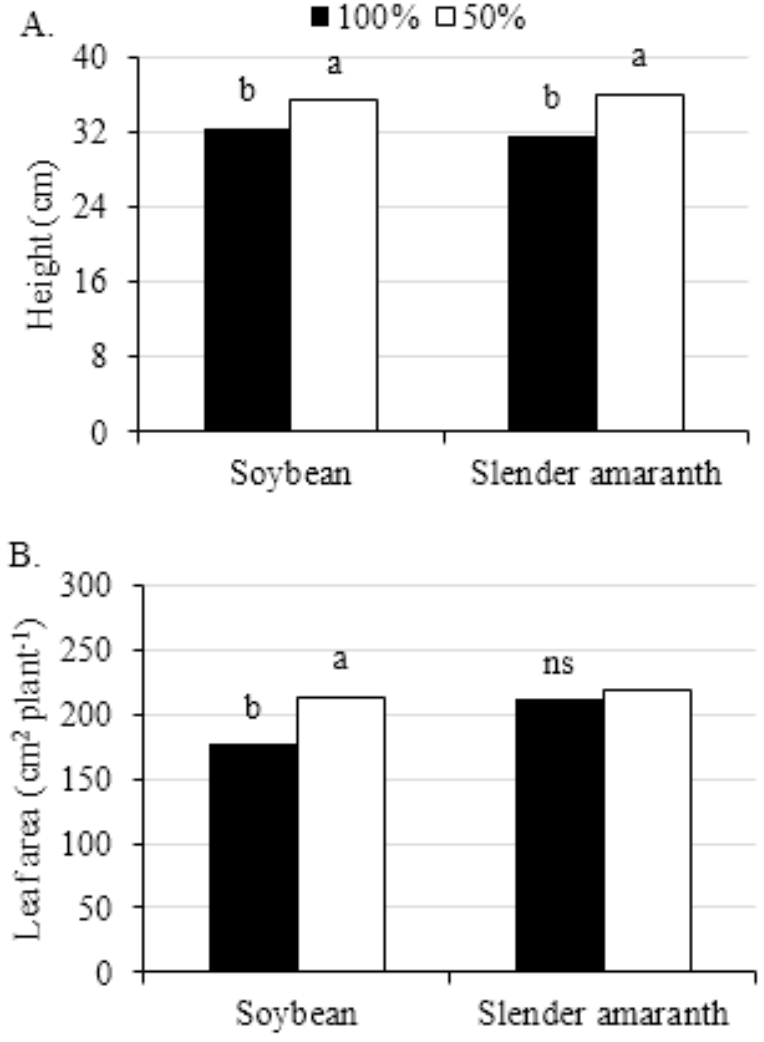
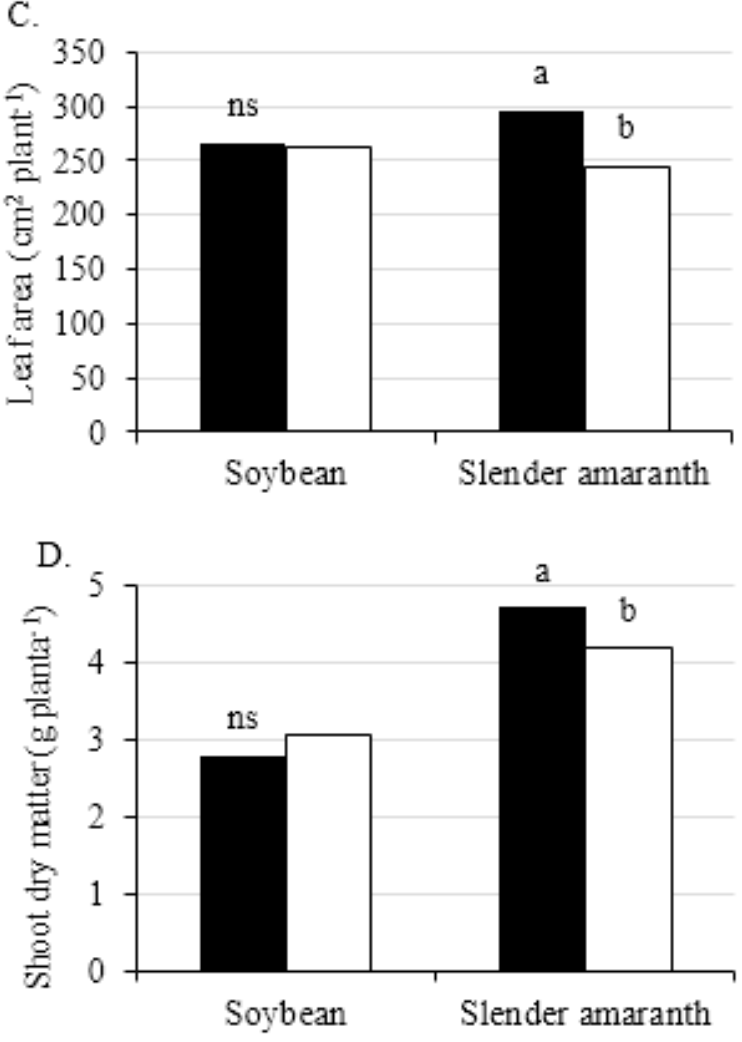

Figure 5. Height, leaf area and shoot dry matter of different proportions (100 and 50\%) of soybean and slender amaranth plants in competition at 45 DAT $(A$ and $B)$ and 55 DAT $(C$ and $D)$, respectively. ${ }^{\text {ns }}$ Non-significant by the F-test $(p>0.05)$. Small letters compare different plant proportions for every species by the T-test $(p \leq 0.05)$.

on redroot pigweed depended on plant density; the larger the number of plants, the higher the shoot dry matter of the weed. Freitas et al. (2019) showed that interspecific competition decreased the growth of corn and signal grass (Urochloa decumbens) plants and intensified negative effects of water deficit on these species.

Understanding the effects of either resource limitation or excess on plants is important, but studies have usually only focused on the evaluation of isolated stress factors, such as abiotic ones. They do not consider competition with weeds or just take into account the effect of competition with the exclusion of other environmental influences.

Understanding the behavior of plants when they are exposed to multiple stresses simultaneously rather than to an isolated factor requires potential interrelations among them to be analyzed. So far, little is known about the effect of weather changes on the interaction between crops and weeds. Thus, identification of combined responses of soybean competing with slender amaranth and associated with abiotic factors enables key issues of weed science to be deeply investigated.

\section{Conclusions}

Soybean crop in cycle $\mathrm{C}_{3}$ exhibits competitiveness which is equivalent to slender amaranth $\left(\mathrm{C}_{4}\right)$, regardless of the water regime under study.

When there is water stress, intraspecific competition negatively influences the morphological parameters of soybean.
There was a general decrease in morphological parameters of slender amaranth in water deficit conditions.

After irrigation conditions reverted to normality, there was a decrease in morphological parameters of soybean.

Interspecific competition generally decreases the morphological parameters of slender amaranth.

\section{Acknowledgments}

This study was partly financed by the Coordenação de Aperfeiçoamento de Pessoal de Nível Superior - Brasil (CAPES) - Finance Code 001. The authors thank the Universidad de Costa Rica for the scholarship awarded to Andrés Antonio Monge Vargas. To CNPq for financial support for Research/N. Proc. 406224/2016-1. To CNPq for the Research Fellowship of author Dr. Dirceu Agostinetto /N.Proc. 308363/2018-3 CNPq.

\section{Literature Cited}

Agostinetto, D.; Fontana, L.C.; Vargas, L.; Perboni, L.T.; Polidoro, E.; Silva, B.M. Competition periods of crabgrass with rice and soybean crops. Planta Daninha, v.32, n.1, p.31-38, 2014. https:// doi.org/10.1590/S0100-83582014000100004.

Bianchi, M.A.; Fleck, N.G.; Agostinetto, D.; Rizzardi, M.A. Interferência de Raphanus sativus na produtividade de cultivares de soja. Planta Daninha, v.29, n.4, p.783-792, 2011. https://doi. org/10.1590/S0100-83582011000400008. 
Bianchi, M.A.; Fleck, N.G.; Lamego, F.P. Proporção entre plantas de soja e plantas competidoras e as relações de interferência mútua. Ciência Rural, v.36, n.5, p.1380-1387, 2006. https://doi. org/10.1590/S0103-84782006000500006.

Cousens, R. Aspects of the design and interpretation of competition (interference) experiments. Weed Technology, v.5, n.3, p.664673, 1991. https://doi.org/10.1017/S0890037X00027524.

Desclaux, D.; Huynh, T.; Roumet, P. Identification of soybean plant characteristics that indicate the timing of drought stress. Crop Science, v.40, n.3, p.716-722, 2000. https://doi.org/10.2135/ cropsci2000.403716x.

Far, F.G.; Mahmoodi, S.; Zamani, G.R.; Zahan, M.H.S. Effect of drought stress on water use efficiency and root dry weight of wheat (Triticum aestivum L.) and rye (Secale cereale L.) in competition conditions. Iranian Journal of Field Crops Research, v.15, n.2, p.438-450, 2017. https://jcesc.um.ac.ir/article/view/53314/12523. 12 Nov. 2019.

Farias, J.R.B.; Neumaier, N.; Nepomuceno, A.L. Soja. In: Monteiro, J.E.B.A (Org.). Agrometeorologia dos cultivos: o fator meteorológico na produção agrícola. 1.ed. Brasília: INMET, 2009. p.263-277.

Freitas, C.D.M.; Oliveira, F.S.; Mesquita, H.C.; Cortez, A.O.; Porto, M.A.F.; Silva, D.V. Effect of competition on the interaction between maize and weed exposed to water deficiency. Revista Caatinga, v.32, n.3, p.719729, 2019. https://doi.org/10.1590/1983-21252019v32n316rc.

Galon, L.; Tironi, S.P.; Rocha, P.R.R.; Concenço, G.; Silva, A.F.; Vargas, L.; Silva, A.A.; Ferreira, E.A.; Minella, E.; Soares, E.R.; Ferreira, F.A. Habilidade competitiva de cultivares de cevada convivendo com azevém. Planta Daninha, v.29, n.4, p.771-781, 2011. https://doi. org/10.1590/S0100-83582011000400007.

Galon, L.; Trevisol, R.; Forte, C.T.; Tironi, S.P.; Júnior, F.W.R.; Radunz, A.L. Competitive ability of bean cultivars with beggarticks. Revista Caatinga, v.30, n.4, p.855-865, 2017. https://doi. org/10.1590/1983-21252017v30n405rc.

Hoffman, M.L.; Buhler, D.D. Utilizing Sorghum as a functional model of crop-weed competition. I. Establishing a competitive hierarchy. Weed Science, v.50, n.4, p.466-472, 2002. https://doi. org/10.1614/0043-1745(2002)050[0466:USAAFM]2.0.CO;2.

Lamego, F.P.; Ruchel, Q.; Kaspary, T.E.; Gallon, M.; Basso, C.J.; Santi, A.L. Habilidade competitiva de cultivares de trigo com plantas daninhas. Planta Daninha, v.31, n.3, p.521-531, 2013. https://doi. org/10.1590/S0100-83582013000300004.

Ma, X.; Wu, H.; Jiang, W.; Ma, Y.; Ma, Y. Interference between redroot pigweed (Amaranthus retroflexus L.) and cotton (Gossypium hirsutum L.): growth analysis. Plos One, v.10, n.6, p.1-18, 2015. https://doi.org/10.1371/journal.pone.0130475.

Meneses, C.H.S.G.; Lima, L.H.G.M.; Lima, M.M.A.; Vidal, M.S. Aspectos genéticos e moleculares de plantas submetidas ao déficit hídrico. Revista Brasileira de Oleaginosas e Fibrosas, v.10, n.1/2, p.1039-1072, 2006.
Morando, R.; Silva, A.O.; Carvalho, L.C.; Pinheiro, M.P.M.A. Déficit hídrico: efeito sobre a cultura da soja. Journal of Agronomic Sciences, v.3, n. especial, p.114-129, 2014. http://www.dca.uem. br/V3NE/10.pdf. 12 Nov. 2019.

Radosevich, S.; Holt, J.; Ghersa, C. Ecology of weeds: relationship to agriculture and natural resource management. 3.ed. Hoboken: John Wiley and Sons, 2007. 150p.

Radosevich, S.R. Methods to study interactions among crops and weeds. Weed Technology, v.1, n.3, p.190-198, 1987. https://doi. org/10.1017/S0890037X00029523.

Rizzardi, M.A.; Roman, E.S.; Borowski, D.Z.; Marcon, R. Interferência de populações de Euphorbia heterophylla e Ipomoea ramosissima isoladas ou em misturas sobre a cultura de soja. Planta Daninha, v.22, n.1, p.29-34, 2004. https://doi.org/10.1590/s010083582004000100004.

Ruchel, Q.; Agostinetto, D.; Zandoná, R.R.; Ulguim, A.da.R.; Neto, R.A; Fraga, D.S. Competitive ability of soybean crop with $C_{3}$ and $\mathrm{C}_{4}$ weeds. International Journal of Agriculture and Environmental Research, v.5, n.5, p.669-683, 2019. https://ijaer.in/2019files/ ijaer_05_54.pdf. 12 Nov. 2019.

Silva, A.F.; Concenço, G.; Aspiazú, I.; Ferreira, E.A.; Galon, L.; Coelho, A.T.C.P.; Silva, A.A.; Ferreira, F.A. Interferência de plantas daninhas em diferentes densidades no crescimento da soja. Planta Daninha, v.27, n.1, p.75-84, 2009. https://doi.org/10.1590/ S0100-83582009000100011.

Silva, D.R.O. da.; Agostinetto, D.; Vargas, L. Development stages horseweed in soybeans competition. Arquivos do Instituto Biológico, v.84, p.1-7, 2017. https://doi.org/10.1590/18081657000202015.

Soares, M.M.; Freitas, C.D.M.; Oliveira, F.S.; Mesquita, H.C.; Silva, T.S.; Silva, D.V. Effects of competition and water deficiency on sunflower and weed growth. Revista Caatinga, v.32, n.2, p.318328, 2019. https://doi.org/10.1590/1983-21252019v32n204rc.

Valerio, M.; Tomecek, M.B.; Lovelli, L.; Ziska, L.H. Quantifying the effect of drought on carbon dioxide induced changes in competition between a $C_{3}$ crop (tomato) and a $C_{4}$ weed (Amaranthus retroflexus). Weed Research, v.51, n.6, p.591-600, 2011. https://doi.org/10.1111/j.1365-3180.2011.00874.x.

Vivian, R.; Dourado-Neto, D.; Silva, A.A.; Victoria Filho, R.; Yeda, M.P.; Ruiz-Corrêa, S. Análise de crescimento de erva-de-touro em competição com soja cultivada sob deficiência hídrica. Planta Daninha, v.31, n.13, p.599-610, 2013. https://doi.org/10.1590/ S0100-83582013000300012.

Wijewardana, C.; Alsajri, F.A.; Irby, J.T.; Krutz, L.J.; Golden, B.; Henry, W.B.; Gao, W.; Reddy, K.R. Physiological assessment of water deficit in soybean using midday leaf water potential and spectral features. Journal of Plant Interactions, v.14, n.1, p.533-543, 2019. https://doi.org/10.1080/17429145.2019.1662499. 